\title{
IN-VITRO FERTILIZATION OF MOUSE OVA WITHIN THE EXPLANTED FALLOPIAN TUBE
}

\author{
R. L. BRINSTER AND J. D. BIGGERS \\ King Ranch Laboratory of Reproductive Physiology, School of Veterinary Medicine, \\ University of Pennsylvania, Philadelphia, Pennsylvania, U.S.A.
}

(Received 19th May 1965)

In 1959, Chang provided the first irrefutable proof of fertilization of mammalian ova in vitro. Since that time, fertilization of rabbit ova in vitro has been done by a number of workers. More recently, Yanagamachi \& Chang (1963, 1964) have succeeded in fertilizing in vitro the eggs of the golden hamster. This was established microscopically and by the cleavage of some of the ova to the twocell stage. No one has yet succeeded in fertilizing mouse ova in vitro. This report describes a method for fertilizing mouse ova in vitro and obtaining the successive cleavage stages up to the blastocyst.

The unfertilized ova were obtained from random-bred Swiss mice which were superovulated by an intraperitoneal injection of 10 i.u. of pregnant mare serum gonadotrophin (Gestyl, Organon), followed $48 \mathrm{hr}$ later by an intraperitoneal injection of 10 i.u. of human chorionic gonadotrophin (Pregnyl, Organon). Since ovulation occurs 11 to $14 \mathrm{hr}$ after HCG injection (Edwards \& Gates, 1959), unfertilized ova of various ages can be obtained by varying either or both the time of injection and the time of the experiment. The ova used in these experiments were not removed from the Fallopian tube until the 4th day after HCG injection (the day following HCG was designated Day 1), at which time the ova should have been morulae or early blastocysts if fertilization had taken place.

At the time of the experiment, the Fallopian tubes containing the ova were aseptically removed from the mice and placed in contact with spermatozoa. During the course of the investigation, it appeared that two methods of bringing spermatozoa into contact with the unfertilized ova gave the best results. In the first method, the ampulla containing the ova was incubated at 32 to $37^{\circ} \mathrm{C}$ with the spermatozoal suspension for 15 to $30 \mathrm{~min}$. In the second method, 2 to $5 \mu \mathrm{l}$ of the spermatozoal suspension was forced into the fimbrial end of the Fallopian tube with a fine pipette before the ampulla was cut free of the lower two-thirds of the oviduct. The medium employed in these experiments was Brinster's medium for ovum culture (BMOC) with $3.16 \times 10^{-4} \mathrm{M}$ pyruvate and supplemented with $1 \mathrm{mg} / \mathrm{ml}$ of glucose (Brinster, 1965). This medium was used for suspending spermatozoa, manipulating oviducts, and for supporting the oviducts during the 4 days of culture. The spermatozoa were obtained by aseptically removing the epididymides and vasa deferentia from a mature male mouse. These were minced in $0.5 \mathrm{ml}$ of medium and kept covered at 32 to 
$37^{\circ}$ C. Although some agglutination of spermatozoa did occur, good motility was usually maintained for 2 to $3 \mathrm{hr}$.

The method used to cultivate the Fallopian tubes containing the ova and spermatozoa was based on a method previously described by Biggers, Gwatkin \& Brinster (1962). However, in the experiments described here, only the ampulla of the Fallopian tube was cultivated. In addition, the explants were placed on tea-bag paper in $0.5 \mathrm{ml}$ of medium in a watch glass. The medium was changed on the 2nd day of cultivation. The results of the experimental procedure were determined by flushing all the ova from the tube on the 4th day of cultivation and determining the number of normal morulae and blastocysts. Further details of the cultivation method will be published elsewhere (Whittingham, unpublished).

TABLE 1

NUMBER OF MORULAE AND BLASTOCYSTS DEVELOPED FROM MOUSE OVA FERTILIZED WITHIN THE EXPLANTED FALLOPIAN TUBE

\begin{tabular}{c|c|c|c|c|c}
\hline Experiment & $\begin{array}{c}\text { No. } \\
\text { mice }\end{array}$ & $\begin{array}{c}\text { No. } \\
\text { ova }\end{array}$ & $\begin{array}{c}\text { No. } \\
\text { morulae }\end{array}$ & $\begin{array}{c}\text { No. } \\
\text { blastocysts }\end{array}$ & $\begin{array}{c}\text { Estimated time } \\
\text { of fertilization } \\
\left.\text { (hr after } \text { HCG }^{*}\right)\end{array}$ \\
\cline { 2 - 4 } & 12 & 95 & 9 & 1 & 19 to 21 \\
2 & 12 & 79 & 4 & 2 & 19 to 20 \\
3 & 12 & 96 & 4 & 7 & $15 \cdot 5$ to 17 \\
4 & 9 & 50 & 1 & 0 & 18 \\
5 & 12 & 119 & 26 & 8 & 17 to 19 \\
6 & 11 & 192 & 15 & 2 & $18 \cdot 5$ to 20 \\
7 & 11 & 125 & 12 & 0 & $14 \cdot 5$ to $17 \cdot 5$ \\
8 & 11 & 73 & 7 & 0 & 18 to $18 \cdot 5$ \\
9 & 9 & 108 & 1 & 4 & 17 to 18 \\
10 & 9 & 78 & 0 & 0 & 18 to 20 \\
11 & 18 & 286 & 1 & 4 & 17 to 21 \\
12 & 13 & 188 & 13 & 3 & 17 to 21 \\
13 & 15 & 259 & 12 & 39 & $14 \cdot 5$ to 21 \\
Total & 154 & 1748 & 105 & 70 & \\
\hline
\end{tabular}

* The number of hours after HCG is the time after the ovulatory injection of human chorionic gonadotrophin when spermatozoa were placed in or near the Fallopian tube containing the ova and the contact resulted in the development of a morula or blastocyst.

A total of thirteen experiments was done. The results of these experiments are shown in Table 1. Of 1748 ova which were recovered, 175 had developed into morulae and blastocysts. Therefore, at least $10 \%$ of the ova had been fertilized in vitro and developed normally. It is not possible to determine how many of the remaining ova, some of which had undergone cleavage, failed to develop because of adverse culture conditions and not because of faulty fertilization. Nevertheless, these experiments show that fertilization definitely occurs in this system.

The last column of Table 1 indicates that ova could be fertilized at any time between 14.5 and $21.0 \mathrm{hr}$ after the injection of $\mathrm{HCG}$. If we assume that ovulation occurs between 11 and $14 \mathrm{hr}$ after HCG (Edwards \& Gates, 1959), the results indicate that mouse ova are capable of being fertilized during a period of at least 3 to $7 \mathrm{hr}$ after ovulation. No attempt was made in the present study to establish lower and upper limits of fertilizable life, but such limits could be established with the method described in this paper. A group of blastocysts developed from ova fertilized in vitro are shown in Plate 1. These blastocysts 
PLATE 1

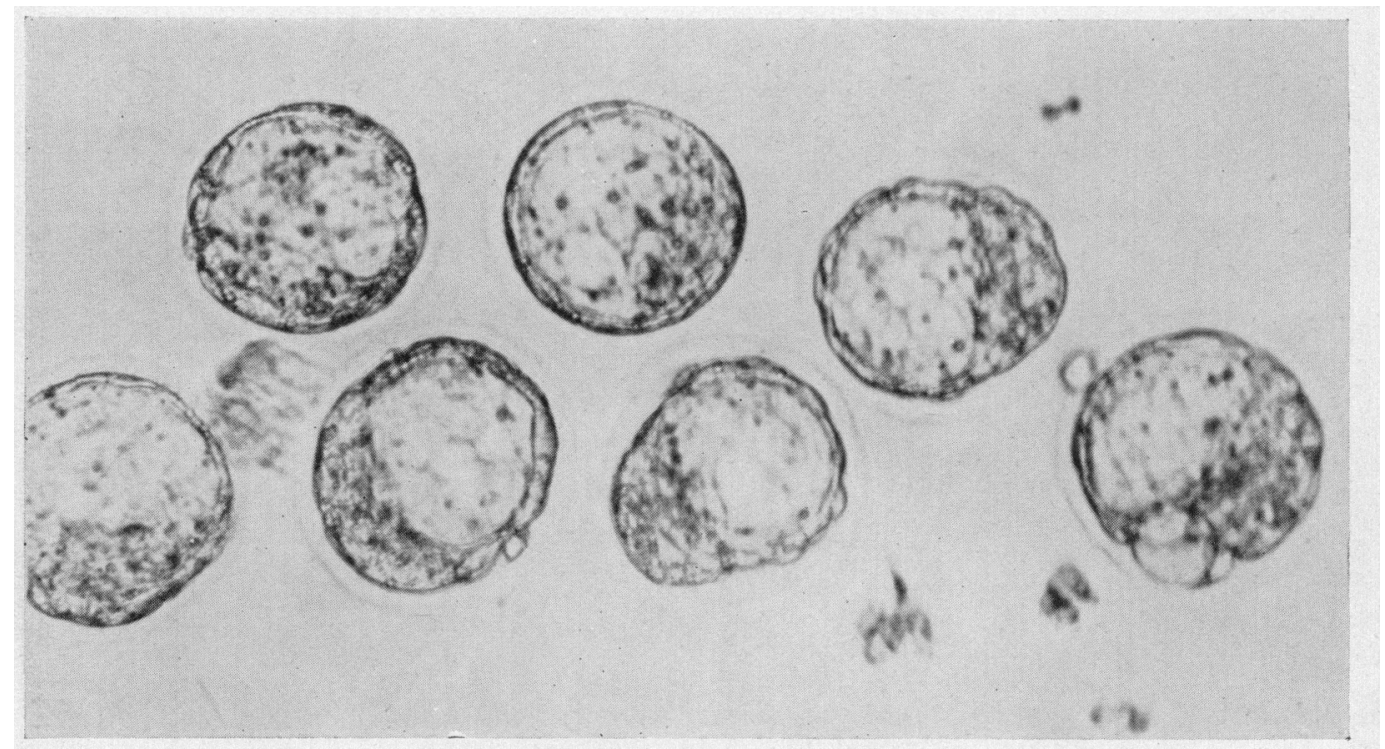

Blastocysts from mouse ova fertilized in vitro. $\times 60$.

(Facing p. 278) 
are normal in appearance and size. The developmental time in the in-vitro system does not appear to be lengthened for those ova which are fertilized and develop to morulae and blastocysts.

A comparison of the two methods of exposing the ova to spermatozoa is shown in Table 2. Although a slightly higher percentage of morulae and blastocysts developed in the tubes incubated in the spermatozoal suspension, as compared to those tubes into which spermatozoa were injected, the difference is not significant $\left(\chi^{2}(1)=1.61, P>0.05\right)$. In addition, there is little difference between the groups in the number of ova showing cleavage. Consequently, it is probably better to incubate the tubes in the spermatozoal suspension, since this is the easier of the two procedures.

TABLE 2

COMPARISON OF INCUBATING FALLOPIAN TUBE IN SPERMATOZOA AND INJECTING SPERMATOZOA INTO FALLOPIAN TUBE

(Data of Experiments 12 and 13 from Table 1)

\begin{tabular}{c|c|c|c|c|c}
\hline Tube & $\begin{array}{c}\text { No. } \\
\text { ova }\end{array}$ & $\begin{array}{c}\text { No. } \\
\text { cleaved }\end{array}$ & $\begin{array}{c}\text { No. } \\
\text { morulae }\end{array}$ & $\begin{array}{c}\text { No. } \\
\text { blastocysts }\end{array}$ & $\begin{array}{c}\text { Morulae and } \\
\text { blastocysts (\%) }\end{array}$ \\
\cline { 2 - 5 } & 235 & 52 & 15 & 25 & $17 \cdot 0$ \\
Total & 212 & 59 & 10 & 17 & $12 \cdot 7$ \\
\hline
\end{tabular}

$\mathrm{a}=$ Fallopian tube incubated with spermatozoa for $20 \mathrm{~min}$.

b = Spermatozoa injected into Fallopian tube.

Number cleaved are those ova which cleaved at least once but did not become morulae or blastocysts. Ova which degenerated or fragmented were not counted as being cleaved.

Although the percentage of normal morulae and blastocysts developing from the in-vitro fertilization is not high $(10 \%)$ when all the experiments are combined, it seems likely that this percentage could be increased as the method is improved. In fact, in Experiment 13, the percentage of recovered ova which had developed into morulae and blastocysts was 19.7 and the percentage of ova showing cleavage was $45 \cdot 2$. The method described provides a means for studying the effects of environment on fertilization and for determining the fertilizable life of the ovum under various conditions.

This work was supported by a grant from the Population Council, Inc., and Grant CA-06638 from the National Cancer Institute, United States Public Health Service.

\section{REFERENCES}

Biggers, J. D., Gwatkin, R. B. L. \& BRinsteR, R. L. (1962) Development of mouse embryos in organ cultures of Fallopian tubes on a chemically defined medium. Nature, Lond. 194, 747.

BRINSTER, R. L. (1965) Studies on the development of mouse embryos in vitro. III. The effect of energy source. F. exp. Zool. 158, 59.

Chang, M. C. (1959) Fertilization of rabbit ova in vitro. Nature, Lond. 193, 466.

EDwards, R. G. \& Gates, A. H. (1959) Timing of the stages of the maturation divisions, ovulation, fertilization and the first cleavage of eggs of adult mice treated with gonadotrophins. F. Endocrin. 18, 292.

Yanagimachi, R. \& Chang, M. C. (1963) Fertilization of hamster eggs in vitro. Nature, Lond. 200, 281.

Yanagimachi, R. \& Chang, M. C. (1964) In vitro fertilization of golden hamster ova. J. exp. Zool. 156, 361. 